\title{
ANALISIS PENDEKATAN PEMBELAJARAN CTL (CONTEXTUAL TEACHING AND LEARNING) DI SMPN 2 TELUK JAMBE TIMUR, KARAWANG
}

\author{
ABDUL KARIM \\ abdul.depok@gmail.com \\ Program Studi Pendidikan Matematika, Fakultas Teknik, Matematika dan IPA \\ Universitas Indraprasta PGRI Jakarta
}

\begin{abstract}
Abstrak. Tujuan penelitian ini adalah menganalisa pendekatan pembelajaran Contextual Teaching and Learning (CTL) Di SMP Negeri 2 Teluk Jambe Timur.Menghasilkan bahan untuk menganalisa sejauh mana pendekatan pembejaran sudah dijalankan di sekolah. Mengdeskripsikan pendekatan pembelajaran CTL meliputi: a) Perancangan Kegiatan Pembelajaran; b) Pelaksanaan/Proses Kegiatan Pembelajaran; c) Evaluasi Hasil belajar.Metode penelitian yang digunakan adalah penelitian deskriptif.Dalam penelitian ini teknik yang digunakan untuk menggumpulkan data adalah teknik survei.Populasi penelitian adalah semua guru SMP Negeri 2 Teluk Jambe Timur yaitu 31 orang guru. Teknik pengumpualan data yang digunakan melalui penyebaran kuesioner yang telah di uji validitas dan reliabilitas.Hasil penelitian menunjukan bahawa; pelaksanan pendekatan pembelajar kontekstual di SMP Negeri 2 Teluk Jambe Timur telah terlaksana sebesar 71 persen atau memiliki nilai rata-rata 2,85. Serta, 29 persen atau 1,15 dipengaruhi oleh pendekatan pembelajaran lainnya. Pada indikator pertama modeling memiliki nilai ratarata 2,59 atau 64,75 persen telah dilaksanakan oleh guru di sekolah. Pada indikator yang kedua bertanya (Questioning) memiliki nilai rata-rata 3,02 atau 75,5 persen telah dilaksanakan oleh guru disekolah.Pada indikator yang ketiga Learning community (Masyarakat belajar) memiliki nilai rata-rata 3.17 atau 79,25 persen telah dilaksanakan oleh guru disekolah. Pada indikator yang keempat inquiry (menemukan) memiliki nilai rata-rata 2,55 atau 63,75 persen telah dilaksanakan oleh guru disekolah. Pada indikator kelima Konstruktivisme (Constructivism) memiliki nilai rata-rata 3,19 atau 79,25 persen telah dilaksanakan oleh guru disekolah. Pada indikator yang keenam Refleksi (Reflection) memiliki nilai rata-rata 3,44 atau 86 persen telah dilaksanakan oleh guru disekolah. Pada indikator yang ketujuh Penilaian yang sebenarnya (Authentic Assesment) memiliki nilai rata-rata 2,68 atau 67 persen telah dilaksanakan oleh guru disekolah.
\end{abstract}

Kata Kunci: Analisis, Pendekatan Pembelajaran Kontekstual

Abstract. The purpose of this study is to analyze the learning approach Contextual
Teaching and Learning (CTL) In SMP Negeri 2 Teluk Jambe Timur. Produce material to
analyze the extent to which the pursuit approach has been run in school. To describe CTL
learning approach include: a) Design of Learning Activities; B) Implementation or
Process of Learning Activities; C) Evaluation of learning outcomes. The research method
used is descriptive research. In this research the technique used to collect data is survey
technique. The study population is all teachers of SMP Negeri 2 Teluk Jambe Timur that
is 31 teachers. Data collection techniques used through the dissemination of
questionnaires that have been tested for validity and reliability. The results showed that;
Theimplementation of a contextual learner approach in SMP Negeri 2 Teluk Jambe
Timur has been implemented at 71 percent or has an average grade of 2.85 . Also, 29
percent or 1.15 is influenced by other learning approaches. In the first indicator modeling
has an average value of 2.59 or 64.75 percent has been implemented by teachers at
school. In the second question indicator (Questioning) has an average grade of 3.02 or 
75.5 percent has been implemented by teachers in school. In the third indicator the Learning community has an average grade of 3.17 or 79.25 percent has been implemented by school teachers. In the fourth indicator the inquiry (find) has an average value of 2.55 or 63.75 percent has been implemented by teachers in the school. In the fifth indicator of Constructivism has an average value of 3.19 or 79.25 percent has been implemented by teachers in school. On the sixth indicator Reflection has an average grade of 3.44 or 86 percent has been implemented by school teachers. On the seventh indicator Authentic Assessment has an average grade of 2.68 or 67 per cent been implemented by school teachers.

Keywords: Analysis, Contextual Learning Approach

\section{PENDAHULUAN}

Pembelajaran matematika di beberapa sekolah selama ini kurang menarik diajarkan pada siswa. Hal tersebut dipengaruhi oleh faktor-faktor diantaranya: (1) materi pelajaran matematika di SMP banyak berisi konsep abstrak yang sulit dipahami siswa. (2) Penyampaian materi matematika dengan metode ceramah nampaknya kurang optimal dalam meningkatkan aktivitas, minat dan motivasi belajar siswa. (3) Pembelajaran masih kurang mengaitkan ilmu matematika dengan kehidupan sehari-hari siswa. Kondisi tersebut menyebabkan kebosanan, perhatian, minat dan motivasi siswa dalam pembelajaran menjadi rendah. Pembelajaran yang berorientasi berpusat pada guru akan membatasi perkembangan kemampuan berpikir siswa. Rendahnya aktivitas, minat dan motivasi belajar siswa disebabkan adanya anggapan bahwa matematika merupakan ilmu yang memiliki sifat abstrak dan terlalu monoton. Untuk itu guru perlu melakukan pembelajaran matematika melalui kegiatan yang kreatif dan inovatif agar siswa memahami bahwa matematika adalah ilmu yang terkait dengan kehidupan manusia sehari-hari.

Berdasarkan Teori Perkembangan Kognitif Piaget, anak seusia SMP (12-15 tahun) belum sepenuhnya dapat berpikir abstrak, dalam pembelajarannya kehadiran benda-benda konkrit masih diperlukan. Meski begitu harus pula mulai dikenalkan bendabenda semi konkrit. Namun pada level SMP ini, anak sudah mulai dapat menerapkan pola berpikir yang dapat menggiringnya untuk memahami dan memecahkan permasalahan. Kemampuan berpikir seperti ini dapat dikreasikan melalui pembelajaran matematika sebab di dalam matematika terdapat struktur dan karakteristik serta keterkaitan yang kuat dan jelas antara konsep yang satu dengan konsep lainnya, sehingga memungkinkan semua siswa dapat berpikir kemampuan rasional dan nyata.

Salah satu jenis pembelajaran untuk menumbuhkan kesadaran terhadap matematika sebagai ilmu yang terkait dengan kehidupan sehari-hari dan diperkirakan dapat meningkatkan kemampuan berpikir kritis siswa adalah dengan pendekatan kontekstual atau Contextual Teaching and Learning (CTL). Pendekatan CTL (Contextual Teaching and Learning) yakni sebuah sistem belajar yang didasarkan pada filosofi bahwa seorang pembelajar akan mau dan mampu menyerap materi pelajaran jika mereka mampu menyerap makna pelajaran tersebut. Pendekatan CTL pada pembelajaran akan membantu siswa dalam membuat hubungan-hubungan antara materi pelajaran dengan kehidupan nyata sehingga siswa akan mendapatkan makna dari apa yang dipelajarinya dan dapat mengembangkan kemampuan berpikir yang pada akhirnya menumbuh-kembangkan karakter siswa. Pendekatan kontekstual melibatkan tujuh komponen utama pembelajaran, yaitu konstruktivisme, bertanya, menemukan, masyarakat belajar, pemodelan, refleksi, dan penilaian otentik (Depdiknas, 2007). 
Dari ketujuh komponen utama pembelajaran kontekstual ini, sangatlah sinkron dengan upaya memunculkan kemampuan berpikir kritis siswa (Johnson, 2010), terutama pada komponen bertanya, menemukan, dan refleksi. Melalui ketiga komponenini diharapkan siswa mampu memanfaatkan model (pemodelan) yang ada, kemudianmengkonstruksi pemahaman sendiri (konstruktivis) terhadap apa yang dipelajarinya. Tentunya pembelajaran yang dirancang demi tercapainya tujuan dalam pendekatan kontekstual ini yakni melalui masyarakat belajar, dan penilaian yang dilakukan tidak terpaku pada hasil akhir saja, namun mempertimbangkan juga proses selama pembelajaran berlangsung demi mewujudkan penilaian yangmenyeluruhdan sebenar-benarnya.

\section{TINJAUAN PUSTAKA}

\section{Hakikat Belajar}

Hamalik (2009: 27) mendefinisikan belajar yaitu modifikasi atau memperteguh kelakuan melalui pengalaman (learning is defined as the modification or strengthening of behavior through experiencing)." karena semakin banyak seseorang belajar maka pengalaman yang diterima akan semakin besar dan akan memperteguh sikap dan kelakuannya pada kemudian hari.

Definisi belajar yang lain diungkapkan oleh Djamarah (2002:13) yang mendefinisikan tentang belajar, yaitu "serangkaian kegiatan jiwa raga untuk memperoleh suatu perubahan tingkah laku sebagai hasil dari pengalaman individu dalam interaksi dengan lingkungannya yang menyangkut kognitif, afektif dan psikomotor". Hal ini semakin memperkuat teori sebelumnya bahwa belajar berkaitan dengan pengalaman seseorang yang diterima padapendidikan formal, informal dan non formal, sehingga memperoleh perubahan perilaku dalam hidupnya.Belajar juga proses perubahan akibat dari pengalaman seseorang. Menurut Hilgard (Ningrum, 2014:164) bahwa belajar merupakan proses mencari ilmu yang terjadi dalam diri seseorang melalui latihan, pembelajaran, dan sebagainya sehingga terjadi perubahan dalam diri. Perubahan perilaku tersebut diperoleh dari hasil interaksi diri individu tersebut dengan lingkungannya. Pengaruh yang ditimbulkan dengan adanya interaksi dengan lingkungannya tersebut akan membuat perubahan tingkah laku keseluruhan secara tetap.

Definisi belajar menurut beberapa pakar pendidikan yang dikutip oleh Ahdiyat dan Sarjaya (2014: 73) sebagai berikut: a) Gagne, mengatakan belajar adalah perubahan disposisi atau kemampuan yang dicapai seseorang melalui aktivitas. Perubahan disposisi tersebut bukan diperoleh langsung dari proses pertumbuhan seseorang secara alamiah, b) Travers, mengatakan belajar adalah proses menghasilkan penyesuaian tingkah laku, c) Cronbach, mengatakan learning is shown by a change in behavior as aresult of experience (belajar adalah perubahan perilaku sebagai hasil dari pengalaman), d) Harold Spears, mengatakan learning is to observe, to read, to imitate, to try something themselves, to listen, to follow direction (belajar adalah mengamati, membaca, meniru, mencoba sesuatu, mendengar, dan mengikuti arah tertentu), e) Geoch, mengatakan learning is change in performace as a result of practice (belajar adalah perubahan prestasi sebagai hasil latihan, dan f) Morgan, mengatakan learning is any relatively permanent change in behavior that is result of past experience (belajar adalah perubahan perilaku yang bersifat permanen sebagai hasil dari pengalaman).

Perubahan dalam diri seseorang merupakan akibat dari interaksi dengan lingkungannya dan proses mental dalam diri mereka yang bertujuan untuk memperoleh pengetahuan. Menurut Amir (2010:90) "belajar adalah suatu tindakan sadar yang dilakukan individu untuk memperoleh perubahan dalam diri mereka atas stimulasi lingkungan dan proses mental mereka sehingga bertambah pengetahuannya." Stimulasi 
lingkungan ini berupa respon dari lingkungan sehingga berubahnya perilaku seseorang. Sedangkan proses mental berupa proses berpikir dan merasakan dari individu.

Berdasarkan uraian tersebut di atas, maka dapat disimpulkan bahwa belajar adalah pengetahuan atau keterampilan yang dikuasai dan dimiliki oleh siswa setelah menerima pengalaman belajar di sekolah dan interaksi dengan lingkungan berupa pengetahuan, pemahaman konsep, perhitungan dan pemecahan masalah tertentu.

\section{Pendekatan Pembelajaran Kontekstual}

Pendekatan pembelajaran kontekstual merupakan konsep belajar yang membantu guru mengaitkan antara materi yang diajarkanya dengan situasi dunia nyata siswa sesuai konteks yang ada pada lingkungan. Menurut Suprijono (2009:79), pendekatan pembelajaran kontekstual atau Contexstual Teaching and Learning (CTL) merupakan konsep yang membantu guru mengaitkan antara materi yang diajarkannya dengan situasi dunia nyata, dan mendorong siswamembuat hubungan antara pengetahuanyang dimilikinya dengan penerapannya dalam kehidupan mereka sebagai anggota keluarga dan masyarakat. Pembelajaran kontekstual merupakan prosedur pembelajaran yang mengubungkan kehidupan siswa dengan lingkungan sosial dan kebiasaan dimasyarakat. Maka, tujuan pembelajaran bukan hanya berpengaruh terhadap hasil belajar melainkan kebermaknaan pengetahuan dan pengalaman yang bermanfaat.

Jhonson (2006: 15) mengungkapkan bahwa pendekatan kontekstual adalah pembelajaran yang bertujuan menolong siswa melihat makna di dalam materi akademik dengan konteks kehidupan keseharian mereka, yaitu dengan konteks keadaan pribadi, sosial, dan budaya mereka. Ini dapat dimaknai, siswa dapat mengaitkan pembelajaran di dalam kelas dengan lingkungan masyarakat dimana siswa tinggal untuk menemukan konteks pemaknaan yang dimaksud.

Sanjaya (2006: 109) mengemukakanbahwa pendekatan pembelajaran kontekstual adalah suatu pendekatan pembelajaran yang menekankan kepada proses keterlibatan siswa secara penuh, untuk dapat memahami materi yang dipelajari, dan menghubungkannya dengan situasi kehidupannyata, sehinggamendorongsiswauntukdapat menerapkannya dalam kehidupan mereka. Dalam pendekatan pembelajaran kontekstual siswa terlibat banyak dalam memaknai pembelajaran yang di berikan dan menerapkan dalam kehidupan sehari-hari.

Pernyataan selaras juga diungkapkan oleh Komalasari (2010:7), bahwa pendekatan pembelajaran kontekstual adalah pendekatan pembelajaran yang meenghubungkan antara materi yang dipelajari dengan kehidupan nyata siswa dalam kehidupan sehari-hari, baik dalam lingkungan keluarga, sekolah, masyarakat maupun warga negara, dengan tujuan untuk menemukan makna materi tersebut bagi kehidupannya.

Berdasarkan beberapa pendapat yang telah dikemukakan dapat di tarik kesimpulan, pembelajaran kontekstual menekankan pada multiaspek lingkungan belajar seperti ruang kelas, laboratorium, lingkungan sekitar dan sebaginya. Pembelajaran Kontekstual menganjurkan para pendidik unruk memilih atau mendesain lingkungan pembelajaran yang memadukan sebanyak mungkin pengalaman belajar seperti lingkungan sosial, budaya, fisik, dan lingkungan psikologis untuk mencapai tujuan pembelajaran. Siswa diharapkan dapat menemukan hubungan yang bermakna anatara pemikiran yang abstrak dengan penerapan praktis dalam konteks dunia nyata dalam lingkungan pembelajaran.

Pendekatan Kontekstual melibatkan tujuh komponen utama pembelajaran yaitukonstruktivisme (constructivism), menemukan (inquiry), bertanya(questioning), masyarakat belajar (learning community), pemodelan (modeling), refleksi (reflection) dan 
penilaian otentik (authentic assesment). (Depdiknas: 2007). Berikut adalah uraian mengenai ketujuh komponen utam dalam pembelajaran kontekstual:

Senada dengan pendapat diatas Menurut Muslich (2012: 44) pendekatan pembelajaran kontekstual melibatkan tujuh komponen utama:

a. Konstruktivisme (Constructivism)

Konstruktivisme merupakan landasan filosofis pendekatan pembelajaran kontekstual, bahwa pengetahuan dibangun oleh manusia sedikit demi sedikit melalui sebuah proses. Menurut pandangan konstruktivisme, tugas guru adalah memfasilitasi proses tersebut dengan cara: (a) menjadikan pengetahuan bermakna dan relevan bagi siswa; (b) memberi kesempatan siswa menemukan dan menerapkan idenya sendiri; dan (c) menyadarkan siswa agar menerapkan strategi mereka sendiri dalam belajar.

b. Inkuiri (Inquiry)

Inkuiri merupakan bagian inti dari kegiatan pembelajaran berbasis kontekstual. Inkuiri artinya proses pembelajaran didasarkan pada pencarian dan penemuan melalui proses berpikir secara sistematis. Pengetahuan dan keterampilan yang diperoleh siswa diharapkan bukan hasil mengingat seperangkat fakta-fakta, tetapi hasil dari menemukan sendiri.

c. Bertanya (Questioning)

Bertanya adalah cerminan dalam kondisi berpikir. Bertanya dalam pembelajaran dipandang sebagai kegiatan guru untuk mendorong, membimbing, dan menilai kemampuan berpikir siswa. Bagi siswa, kegiatan bertanya dimaksudkan untuk menggali informasi, mengkomunikasikan apa yang sudah diketahui, dan mengarahkan perhatian pada aspek yang belum diketahuinya.

d. Masyarakat Belajar (Learning Community)

Ketika menggunakan pendekatan pembelajaran kontekstual di dalam kelas, guru disarankan selalu melaksanakan pembelajaran dalam kelompok-kelompok belajar. Siswa dibagi dalam kelompok-kelompok yang anggotanya heterogen.

e. Pemodelan (Modeling)

Pemodelan adalah proses pembelajaran dengan memperagakansesuatu contoh yang dapat ditiru oleh setiap siswa.

f. Refleksi (Reflection)

Refleksi adalah cara berpikir tentang apa yang baru dipelajari atau berpikir kebelakang tentang apa-apa yang sudah dilakukan ketika pembelajaran. Nilai hakiki dari komponen ini adalah semangat instropeksi untuk perbaikan pada kegiatan pembelajaran berikutnya.

g. Penilaian Autentik (Authentic Assessment)

Penilaian autentik adalah upaya pengumpulan berbagai data yang dapat memberikan gambaran perkembangan belajar siswa. Data dikumpulkan dari kegiatan nyata yang dikerjakan siswa pada saat melakukan pembelajaran.

\section{METODE}

Metode penelitian yang digunakan adalah penelitian deskriptif. penelitaian deskriptif (Nazil: 2005:63) yaitu suatu metode dalam meneliti status kelompok manusia, suatu objek, suatu kondisi, suatu sistem pemikiran ataupun suatu kelas peristiwa pada masa sekarang yang bertujuan untuk membuat deskripsi, gambaran atau lukisan secara sistematis, faktual dan akurat mengenai fakta-fakta, sifat-sifat serta hubungan antar fenomena yang diselidiki.

Dalam penelitian ini teknik yang digunakan untuk menggumpulkan data adalah teknik survei. Menurut Singarimbun dan Efendi (1996: 5) penelitian survei adalah 
penelitian yang mengambil sampel dari populasi dan menggunakan kuesioner sebagai alat pengumpulan data.

Populasi penelitian adalah semua guru SMP Negeri 2 Teluk Jambe Timur yaitu 31 orang guru. Teknik pengambilan sampel yang digunakan dalam penelitian ini dipilih atas dasar sampel tujuan (purposive sample). Menurut Arikunto (2006: 130), purposive sample adalah penetuan sampel dengan tujuan tertentu.

\section{HASIL DAN PEMBAHASAN}

\section{Karakteristik Responden}

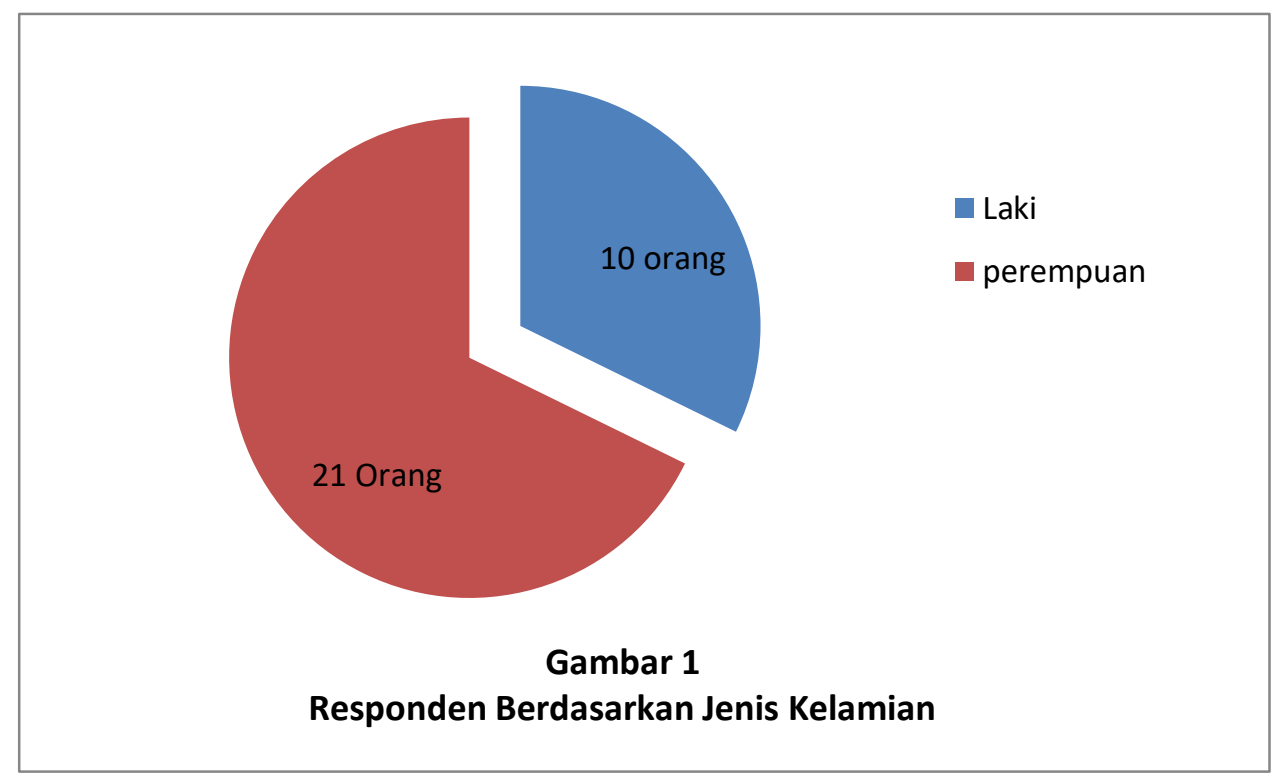

\section{Pembelajaran Kontekstual Disekolah}

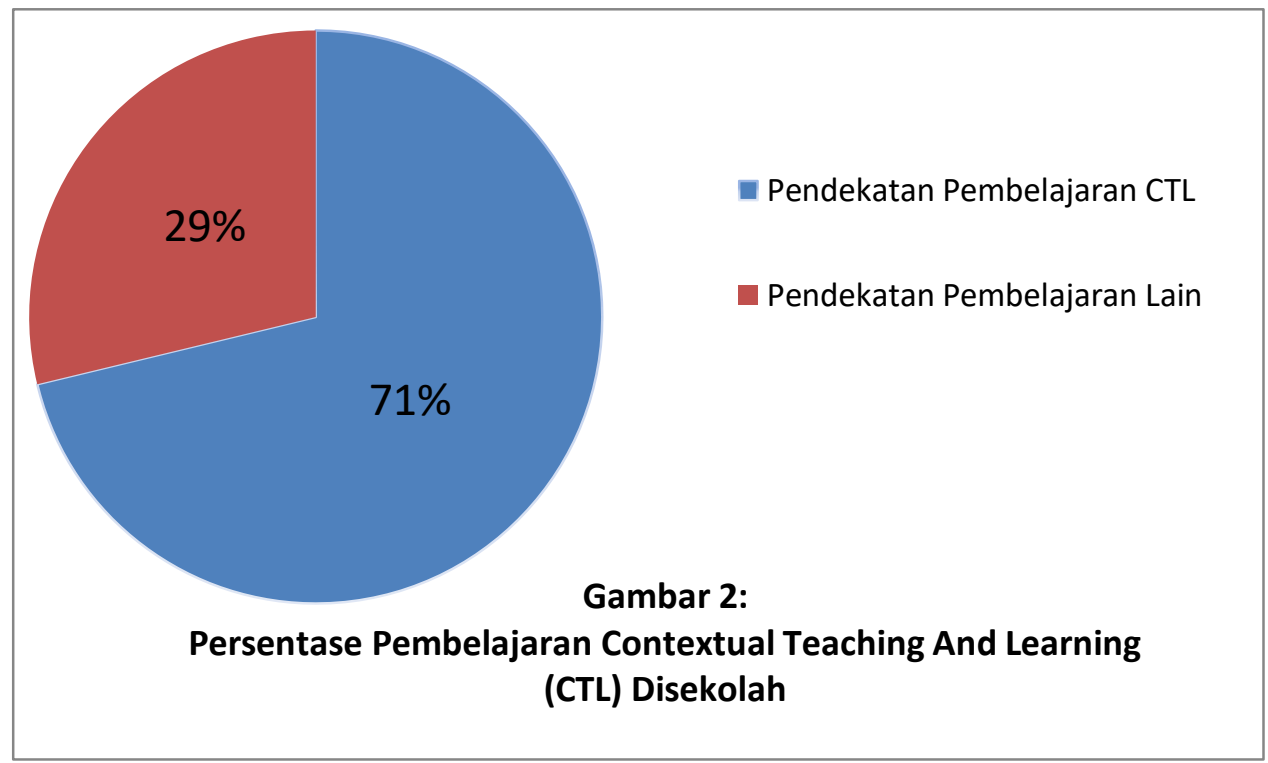




\section{Pendekatan Pembelajaran Konteksual Disekolah}

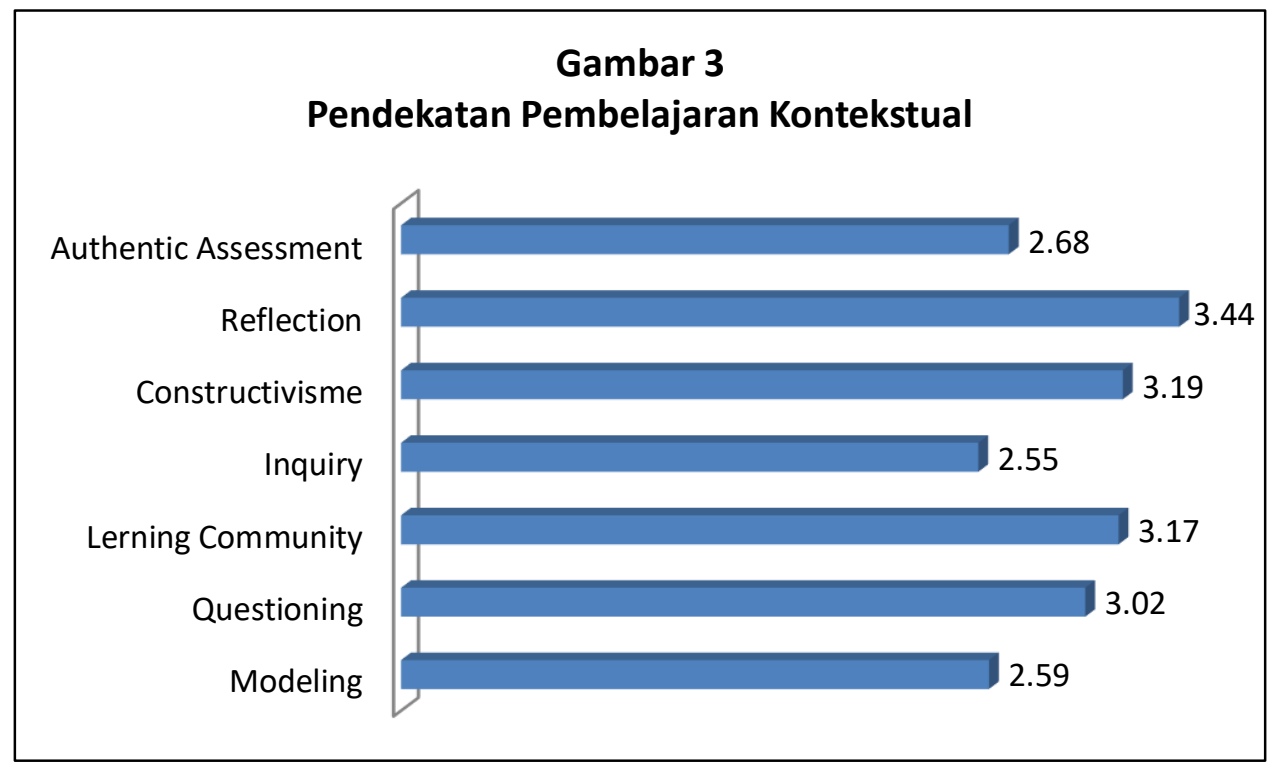

\section{Pembahasan}

Gambar 1 menunjukkan bahwa jumlah responden berjenis kelamin perempuan sebesar 21 orang atau $68 \%$ sedangkan responden berjenis kelamin laki-laki sebesar 10 orang atau $32 \%$.

Analisis pelaksanaan pendekatan kontekstual di SMP Negeri 2 Teluk Jambe Timur disajikan pada gambar 2 persentase pembelajaran contextual teaching and learning yang terbentuk dari tujuh indikator pertanyaan yaitu modeling, questioning, lerning community, inquiry, constructivisme, reflection dan authentic assessment. Ketujuh indikator ini menggambarkan pendekatan pembelajaran kontekstual. Terlihat pada gambar 2 pelaksanan pendekatan pembelajar kontekstual telah terlaksana sebesar 71 persen atau memiliki nilai rata-rata 2,85. Serta, 29 persen atau 1,15 dipengaruhi oleh pendekatan pembelajaran lainnya.

dapat dilihat dari tujuh buah indikator saling terkait satu dengan yang lainnya. Dari gambar 3 didapat indikator terendah pada inquiry dengan nilai rata-rata 2,55 dan indikator tertinggi pada reflection dengan nilai rata-rata 3,44.

Pada indikator yang pertama yaitu Modeling (pemodelan) yang mengarahkan guru untuk memusatkan perhatian, memfokuskan dengan kata kunci dan memahami sebuah contoh dari sebuah permasalahan. Modeling memiliki nilai rata-rata 2,59 atau 64,75 persen telah dilaksanakan oleh guru di sekolah. Hal ini dapat diartikan guru sudah melaksanakan dengan cukup baik dalam pelaksanaan pendektaan pembelajaran kontekstual.

Pada indikator yang kedua bertanya (Questioning) yang bertujuan mendorong, membimbing, menuntun, mengarahkan, mengembangkan pemahaman peserta didik. Questioning memiliki nilai rata-rata 3,02 atau 75,5 persen telah dilaksanakan oleh guru disekolah. Hal ini dapat di artikan guru sudah melaksanakan dengan baik dalam pembelajaran kontekstual.

Pada indikator yang ketiga Learning community (Masyarakat belajar). Indikator ini bertujuan hasil pembelajaran bersumber dari komunikasi dua arah yang bersumber dari teman, pembelajaran kelompok dan berbagai mcam sumber. Learning community memiliki nilai rata-rata 3.17 atau 79,25 persen telah dilaksanakan oleh guru disekolah. 
Hal ini dapat diartikan guru sudah melaksanakan dengan baik dalam pembelajaran kontekstual.

Pada indikator yang keempat inquiry (menemukan). Indikator ini bertujuan agar pengetahuan dan keterampilan peserta didik bukan hanya berdasarkan penghafalan saja melainkan dari sebuah proses penemuan. Inquiry memiliki nilai rata-rata 2,55 atau 63,75 persen telah dilaksanakan oleh guru disekolah. Hal ini dapat diartikan guru sudah melaksanakan dengan cukup baik dalam pembelajaran kontekstual.

Pada indikator kelima Konstruktivisme (Constructivism). Indikator ini merupakan sebuah landasan filosofi dari sebuah pendekatan kontekstual yang memiliki tujuan peserta didik dapat memahami pengetahuan yang baru berdasarkan pengetahuan yang sudah dipahami terlebih dahulu. Konstruktivisme memiliki nilai rata-rata 3,19 atau 79,25 persen telah dilaksanakan oleh guru disekolah. Hal ini dapat diartikan guru sudah melaksanakan dengan baik dalam pembelajaran kontekstual.

Pada indikator yang keenam Refleksi (Reflection). Indikator ini bertujuan untuk mengingat kembali pembelajaran apa saja yang sudah terlaksana dan mengevaluasi berupa pertanyaan langsung kepada peserta didik. Refleksi memiliki nilai rata-rata 3,44 atau 86 persen telah dilaksanakan oleh guru disekolah. Hal ini dapat diartikan guru sudah melaksanakan dengan baik dalam pembelajaran kontekstual.

Pada indikator yang ketujuh Penilaian yang sebenarnya (Authentic Assesment). Indikator ini bertujuan kepada penilaian selama proses pembelajaran berlangsung bukan hanya penilaian koknitifnya saja, melainkan penilaian afektif dan piskomotoriknya. Authentic Assesment memiliki nilai rata-rata 2,68 atau 67 persen telah dilaksanakan oleh guru disekolah. Hal ini dapat diartikan guru sudah melaksanakan dengan cukup baik dalam pembelajaran kontekstual.

Dari ketujuh indikator dapat disimpulkan pendekatan pembelajaran kontektual sudah dilaksanakan dengan baik oleg guru SMP Negeri 2 Teluk Jambe Timur. Yang perlu ditingkatkan pada indikator menemukan (inquiry). Didalam pembelajaran inquiry peserta didik dapat meningkatkan motivasi dan kepercayaan diri.

\section{PENUTUP}

\section{Simpulan}

Berdasarkan pembahasan, maka dapat disimpulkan bahwa:

1. Persentase pembelajaran contextual teaching and learning yang terbentuk dari tujuh indikator pertanyaan yaitu modeling, questioning, lerning community, inquiry, constructivisme, reflection dan authentic assessment. Ketujuh indikator ini menggambarkan pendekatan pembelajaran kontekstual.

2. Pelaksanan pendekatan pembelajar kontekstual di SMP Negeri 2 Teluk Jambe Timur telah terlaksana sebesar 71 persen atau memiliki nilai rata-rata 2,85. Serta, 29 persen atau 1,15 dipengaruhi oleh pendekatan pembelajaran lainnya.

3. Pada indikator pertama modeling memiliki nilai rata-rata 2,59 atau 64,75 persen telah dilaksanakan oleh guru di sekolah. Hal ini dapat diartikan guru sudah melaksanakan dengan cukup baik dalam pelaksanaan pendektaan pembelajaran kontekstual.

4. Pada indikator yang kedua bertanya (questioning) memiliki nilai rata-rata 3,02 atau 75,5 persen telah dilaksanakan oleh guru disekolah. Hal ini dapat di artikan guru sudah melaksanakan dengan baik dalam pembelajaran kontekstual.

5. Pada indikator yang ketiga learning community (masyarakat belajar) memiliki nilai rata-rata 3.17 atau 79,25 persen telah dilaksanakan oleh guru disekolah. Hal ini dapat diartikan guru sudah melaksanakan dengan baik dalam pembelajaran kontekstual. 
6. Pada indikator yang keempat inquiry (menemukan) memiliki nilai rata-rata 2,55 atau 63,75 persen telah dilaksanakan oleh guru disekolah. Hal ini dapat diartikan guru sudah melaksanakan dengan cukup baik dalam pembelajaran kontekstual.

7. Pada indikator kelima konstruktivisme (constructivism) memiliki nilai rata-rata 3,19 atau 79,25 persen telah dilaksanakan oleh guru disekolah. Hal ini dapat diartikan guru sudah melaksanakan dengan baik dalam pembelajaran kontekstual.

8. Pada indikator yang keenam refleksi (reflection) memiliki nilai rata-rata 3,44 atau 86 persen telah dilaksanakan oleh guru disekolah. Hal ini dapat diartikan guru sudah melaksanakan dengan baik dalam pembelajaran kontekstual.

9. Pada indikator yang ketujuh penilaian yang sebenarnya (authentic assesment) memiliki nilai rata-rata 2,68 atau 67 persen telah dilaksanakan oleh guru disekolah. Hal ini dapat diartikan guru sudah melaksanakan dengan cukup baik dalam pembelajaran kontekstual.

\section{Saran}

Berdasarkan keseluruhan dari hasil dan pembahasan penelitian ini, maka diberikan beberapa saran yang diharpkan memberikan manfaat dari hasi penelitian ini. Adapun saran tersebut antara lain:

1. Penggunaan pendekatan kontekstual disekolah membantu peserta didik dalam pempermudah memahami suatu konsep pembelajaran.

2. Guru diharpkan didalam pemberian nilai tidakhanya terpaku dengan penilaian kognitif saja, tetapi juga harus memperhatikan aspek afektif dan pisikomotoriknya.

\section{DAFTAR PUSTAKA}

Ahdiyat, M. dan Sarjaya. 2014. Metode tutor sebaya untuk meningkatkan hasil belajar matematika pada materi pengolahan data. Jurnal Formatif, 4 (1):7179.

Amir, T. M. 2010. Inovasi Pendidikan Melalui Problem Based Learning Bagaimana Pendidikan Memberdayakan Pemelajar di Era Pengetahuan. Jakarta: Kencana Prenada Media Group.

Arikunto, S. 2006. Prosedur Penelitian Suatu Pendekatan Praktek, Edisi Revisi VI. Jakarta: Rineka Cipta.

Depdiknas. 2007. Materi Sosialisasi dan Pelatihan Kurikulum Tingkat Satuan Pendidikan (KTSP) SMP. Jakarta: Pusat Kurikulum Depdiknas.

Hamalik, O. 2009. Psikologi Belajar dan Mengajar. Jakarta: PT Bumi Aksara.

Jhonson, B. E. 2006. Contextual Teaching and Learning. Mizan Learning Center. Bandung.

Johnson, E. B. 2010. Contextual Teaching \& Learning: Menjadikan Kegiatan Belajar-Mengajar Mengasyikkan dan Bermakna. Bandung: Kaifa.

Muslich, M. 2012. Pembelajaran Berbasis Kompetensi dan Kontekstual. Bumi Aksara. Jakarta.

Nazir, M. 2005. Metode Penelitian. Jakarta: PT Ghalia Indonesia.

Ningrum, D. S. dan Leonard. 2014. Pengembangan desain pembelajaran matematika sekolah dasar kelas. Jurnal Formatif, 4 (3): 163-173.

Singarimbum, M. dan Efendi, S. 1996. Metode Penelitian Survei. Jakarta: LP3ES.

Suprijono, A. 2009. Cooperative Learning Teori dan Aplikasi PAIKEM. Pustaka Pelajar. Surabaya. 